\title{
Aphallia: do sociocultural issues affect treatment decisions?
}

\author{
Julio Palacios-Juárez, ${ }^{1}$ Erik Hanson-Viana, ${ }^{2}$ Jorge Humberto Rodríguez-Quintero, ${ }^{3}$ \\ Jesus Morales-Maza ${ }^{3}$
}

'Department of Plastic Surgery, Hospital Regional de Alta Especialidad Ixtapaluca, Ixtapaluca, Mexico

${ }^{2}$ Department of Surgery, Hospital General de Mexico "Dr. Eduardo Liceaga", Mexico city, Mexico

${ }^{3}$ Department of Surgery, Instituto Nacional de Ciencias Médicas y Nutrición "Salvador Zubirán", Mexico City, Mexico

Correspondence to Dr Jorge Humberto RodríguezQuintero, huroqu90@gmail.com

Accepted 28 July 2018

\section{DESCRIPTION}

Otherwise healthy 1-month-old male patient (documented 46,XY karyotype) was referred to the plastic surgery unit for assessment. Physical exam revealed absence of penis and urethra along with a well-formed scrotum and both normally descended testicles (figure 1). No characteristic facial phenotype was noted. Also, there were no abdominal wall hernias nor abnormalities of the anal canal. An echocardiogram, abdominal ultrasound and CT were performed to exclude other malformations. CT scan revealed a functional but hypoplastic right kidney and the presence of a vesicorectal fistula. The rest of the studies including a hormonal profile were within normal limits.

Surgical fistula closure and perineal urethrostomy placement were recommended as initial treatment. Also, the possibility of either early female sexual reassignment or phalloplasty were proposed as long-term options for definitive reconstruction. The parents underwent psychological counselling to help in the decision-making process; detailed information regarding both approaches was given, emphasising the benefits of early reconstruction to allow the child to gender-identify preferentially before toilet training. Considering several factors, including the extremely low-income/resource status of the family and their limited access to health services, feminising genitoplasty was advised, being the only attainable option for the family at that moment.

The parents strongly refuted the suggested procedure and decided to withhold the performance of definitive reconstruction indefinitely, allowing only for fistula correction. Special efforts were taken on educating the family regarding how either delaying or not completing treatment would affect child's development; however, their final decision was maintained.

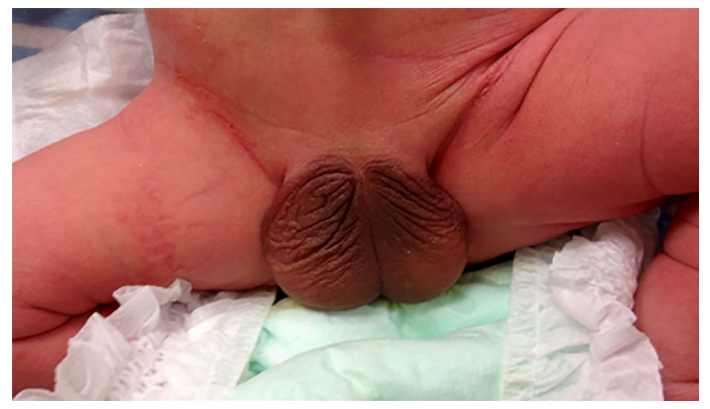

Figure 1 Picture showing the perineal region of the patient.
Aphallia is a rare penile developmental anomaly. It has an incidence of 1 in every 20-30 million births, with $<100$ cases reported globally. It results from an impaired proliferation of mesenchymal cells at the cloacal eminence during the fourth week of gestation leading to absent formation of a genital tubercle. It is characterised by an absent phallus in the context of 46,XY karyotype and no abnormalities in sexual hormones, pituitary gonadal axis or suprarenal cortex. ${ }^{1}$

These patients require a multidisciplinary approach which often includes psychologists, endocrinologists, paediatric urologists, paediatric surgeons, plastic surgeons and social workers; and when possible should be channelled to a thirdlevel centre that has the experience and human resources to treat this condition as a whole, as not all community centres have access to every one of the above-mentioned specialties.

Treatment is controversial. Some groups still recommend early female gender reassignment ${ }^{2}$; however, other techniques have been described aiming for phalloplasty; In 2007 de Castro et al reported a quadrangular lower abdominal adipocutaneous flap for temporary phalloplasty until the patient could undergo definitive reconstruction after puberty. The use of alternative techniques such as anterolateral thigh and latissimus dorsi flaps (Bajpai procedure) have also shown promising results.

Several issues have to be considered to select the most convenient approach for these patients. Sexual designation should be chosen considering the gender that provides the best prognosis in terms of reproductive function, capability of sexual performance, appearance of the external genitalia and self-identity with a specific gender. ${ }^{3}$ Although it is generally accepted that genetic males should be supported surgically until becoming old enough to gender-identify themselves, the decision should be taken on an individual basis as not all patients may have access to both options, specially in low-income settings and low-income, middle-income countries.

Forefront phalloplasty techniques are by far more technically complex procedures and might require an experienced micro surgeon, specific infrastructure and surgical materials (eg, micro sutures and a surgical microscope), trained staff with experience in postoperatory monitoring of flaps and longer hospitalisation periods, which in our case were economically out of reach to the family at the time of consultation. On the other side, in this particular context feminising genitoplasty entailed an initially 
simpler and more achievable approach, which was thoroughly disclosed to the family allowing them to make a well-founded decision; as implied, we explained that although feminising genitoplasty was not free of its own morbidities, such as anastomotic leaks, adhesive bowel obstruction postvaginal interposition, follow-up vaginal dilations at puberty, etc, we considered that such things might most probably arise (If at all) later in the course of the child's development compared with those related to phalloplasty which could appear early and represented a potential risk for his well-being and prognosis if not managed properly and in a timely fashion, which is relevant considering the family lived several hours away from our centre and had limited access to transportation services. We also openly discussed the risk of developing gender dysphoria if assigned the female sex after being imprinted as a male, and the further need of receiving hormone replacement if subjected to this approach.

In addition, by reviewing the previous medical records of the family we found several inconsistencies regarding attendance to prenatal consults, screening studies and well-child visits that seemed to be related with the nature of the parent's occupation, which had them move constantly between small communities. This made us certain that the family was prone to lose follow-up if not committed to a treatment plan from this point. Therefore, after broadly discussing this issue we came to the conclusion that in this particular context providing definitive treatment in an earlier manner could be a better option than risking the child to either not receiving treatment at all or deferring it indefinitely, which is a far more frequent situation encountered in our setting.

It draws our attention that based on several sociocultural concerns mentioned during the interviews the family firmly refuted the approach and decided to defer reconstructive treatment conclusively. Open appointment was given in case the family reconsidered their decision. However, we believe further education on this topic is needed in low-income, middle-income countries to allow for more prudent decision-making.

\section{Learning points}

- Aphallia is a rare penile developmental anomaly with an incidence of 1 in every 20-30 million births.

- Regarding treatment, sexual designation should be chosen considering the gender that provides the best prognosis in terms of reproductive function, sexual performance, appearance and gender identity.

- Treatment decisions should be taken on an individual basis.

Contributors Planning of the study was performed by JP-J, EH-V, JHR-Q and JMM. JHR-Q and JMM were responsible for conducting the study and providing insight. The conception of the case was done by JP-J and EH-V. JHR-Q and JMM were responsible for acquiring the images and data. The paper was written by JP-J, EH-V, JHR-Q and JMM. Case analysis and follow-up were done by JP-J and EH-V. JP-J, EH-V, JHR-Q and JMM approved the final version of the manuscript.

Funding The authors have not declared a specific grant for this research from any funding agency in the public, commercial or not-for-profit sectors.

Competing interests None declared.

Patient consent Parental/guardian consent obtained.

Provenance and peer review Not commissioned; externally peer reviewed.

\section{REFERENCES}

1 Kane AD, Ngom G, Ndour O, et al. Aphallia: a case report and literature review. Afr J Paediatr Surg 2011:8:324-5.

2 Hendren WH. The genetic male with absent penis and urethrorectal communication: experience with 5 patients. J Urol 1997;157:1469-74.

3 Gabler T, Charlton R, Loveland J, et al. Aphallia: a review to standardize management. Pediatr Surg Int 2018;34:813-21.

Copyright 2018 BMJ Publishing Group. All rights reserved. For permission to reuse any of this content visit

http://group.bmj.com/group/rights-licensing/permissions.

BMJ Case Report Fellows may re-use this article for personal use and teaching without any further permission.

Become a Fellow of BMJ Case Reports today and you can:

- Submit as many cases as you like

- Enjoy fast sympathetic peer review and rapid publication of accepted articles

- Access all the published articles

Re-use any of the published material for personal use and teaching without further permission

For information on Institutional Fellowships contact consortiasales@bmjgroup.com

Visit casereports.bmj.com for more articles like this and to become a Fellow 